\title{
Prevalence and time of development of systemic arterial hypertension in patients after liver transplantation
}

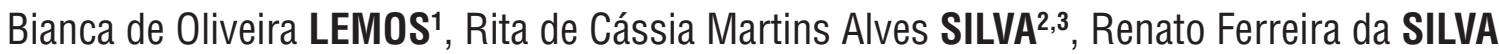

Received: 31 August 2020 Accepted: 15 October 2020

ABSTRACT - Background - The use of immunosuppressive drugs after liver transplantation (LT) is associated with the development of systemic arterial hypertension (SAH), in addition to other comorbidities of metabolic syndrome. Objective - Therefore, the purpose of this study was to analyze the time after use immunosuppressive drugs the patient progresses to $\mathrm{SAH}$, as well as to identify its prevalence and the factors that may be correlated to it. Methods - A retrospective and longitudinal study was conducted, based on the analysis of medical records of 72 normotensive patients, attended in the transplant unit of a university hospital, between 2016 and 2019. Results - It was observed, on average, $9 \pm 6.98$ months after immunosuppressive use, the patients were diagnosed with hypertension, and the prevalence of transplanted patients who evolved to SAH in this study was $59.64 \%$ (41 patients). In addition, there was a correlation between serum dosage of tacrolimus and the development of SAH $(P=0.0067)$, which shows that tacrolimus has a significant role in the development of SAH. Finally, it was noticed that the development of post-transplantation hypertension indicates a higher risk of the patient presenting the other parameters of metabolic syndrome, as well as a higher impairment in its renal function $(P=0.0061)$. Conclusion - This study shows that the patients evolved to SAH in an average of $9 \pm 6.98$ months after immunosuppressive drug use. We have also found high prevalence of systemic arterial hypertension (59.64\%) in patients after liver transplantation, who used calcineurin inhibitors, especially when associated with the use of tacrolimus.

HEADINGS - Liver transplant. Hypertension. Prevalence. Immunosuppressive agents, adverse effects. Tacrolimus.

\section{INTRODUCTION}

The first attempt of liver transplants was performed by Starzl et al. in 1963 in the United States, and in Brazil, this type of transplantation has only occurred for the first time in $1985^{(1)}$. Initially, however, the survival of patients in the first year was low, only after the discovery of the immunosuppressive drug, cyclosporine, there has been a change in the scenario ${ }^{(2)}$. Currently, the main etiologies of liver diseases that lead to liver transplantation are cirrhosis related to viral hepatitis (HCV, HBV), alcohol, non-alcoholic fatty liver disease and chronic hepatitis $\mathrm{C}^{(3)}$. Even with recent advances in surgical techniques and immunosuppression therapies, recent studies $^{(4,5)}$ have shown that patients who have undergone liver transplants tend to have a higher risk of having metabolic syndrome, which include obesity, dyslipidemia, systemic arterial hypertension and hyperglycemia ${ }^{(4)}$.

Systemic arterial hypertension (SAH) manifested after liver transplantation is associated with the use of isolated or associated immunosuppressants, such as calcineurin inhibitors (cyclosporine and tacrolimus), corticosteroids, mTOR (mammalian target of rapamycin inhibitors), in addition to other factors such as alteration of renal function and steatosis ${ }^{(6,7)}$. Calcineurin inhibitors cause widespread arterial vasoconstriction and this promotes sodium re- absorption and, consequently, higher volume of water, which results in increased volemia and thus leads to increased blood pressure ${ }^{(8)}$ Thereby, systemic arterial hypertension is a complication in liver transplants recipients and can have severe influences on quality of life and even on morbidity and mortality of individuals $\mathrm{s}^{(6,8)}$.

This study, therefore, aimed to verify the prevalence of SAH in patients after liver transplantation, in a university hospital, as well as to analyze the factors that could be associated with the presence of hypertension, such as, immunosuppressive drugs and metabolic syndrome.

\section{METHODS}

It concerns a retrospective, longitudinal, cohort study based on the analysis of 213 medical records of patients undergoing liver transplantation in a university hospital from 2015 to 2018. The Research Ethics Committee of FAMERP approved the research project

Were excluded from the research those patients who had previous systemic arterial hypertension or who died within the first five months after transplantation, temporal cutout performed for analysis of the immunosuppressive action. Patients with systolic blood pressure $>140 \mathrm{mmHg}$ and/or diastolic blood pressure $>90$

Declared conflict of interest of all authors: none

Disclosure of funding: Bolsa de Iniciação Científica PIBIC/CNPQ

${ }^{1}$ Faculdade de Medicina de São José do Rio Preto (FAMERP), São José do Rio Preto, SP, Brasil. ${ }^{2}$ Fundação Faculdade Regional de Medicina de São José do Rio Preto (FUNFARME), Hospital de Base, Unidade de Transplante de Fígado, São José do Rio Preto, SP, Brasil. ${ }^{3}$ Faculdade de Medicina de São José do Rio Preto (FAMERP), Departamento de Clínica Médica, São José do Rio Preto, SP, Brasil. ${ }^{4}$ Faculdade de Medicina de São José do Rio Preto (FAMERP), Departamento de Cirurgia, São José do Rio Preto, SP, Brasil.

Corresponding author: Bianca de Oliveira Lemos. E-mail: bianca.olilemos@gmail.com 
$\mathrm{mmHg}$ and/or in antihypertensive use were considered hypertensive. Of the 213 records checked, 141 were excluded because they had previous SAH or died within the first five months after the transplant. Thus, for this research, were studied 72 patients who underwent liver transplantation and met the inclusion criteria. These patients were divided into two groups: Group A $(n=41)$ which included patients who developed systemic arterial hypertension after transplantation and Group B $(n=31)$ which included patients who did not develop systemic arterial hypertension after transplantation.

Demographic and clinical data were analyzed such as age, gender, Child-Pugh (C-P) classification, Model for End-stage Liver Disease, transplant indication. In addition, the prevalence of systemic arterial hypertension after liver transplantation was verified, as well as the time after transplantation in which $\mathrm{SAH}$ developed and the classification according to degree.

Furthermore, body weight variation on the day of admission for the surgery and the body weight 5 months after transplantation were analyzed to verify if there was a statistical difference. The immunosuppressants studied were those prescribed in the first months after transplantation. It was also evaluated the development of diabetes mellitus and the dosage of patients' creatinine at three different times ( 1 day after transplant, in addition 3 months and 6 months after transplantation).

The information obtained was inserted into Excel spreadsheet. All statistical analyses were performed with a significance level = 0.05 . The Mann-Whitney test was used to compare both groups since the data were not parametric, and Spearman's Linear Correlation was used for the correlations.

\section{RESULTS}

Demographic and clinical data of the patients studied are presented in TABLE 1.

TABLE 1. Demographic and clinical data.

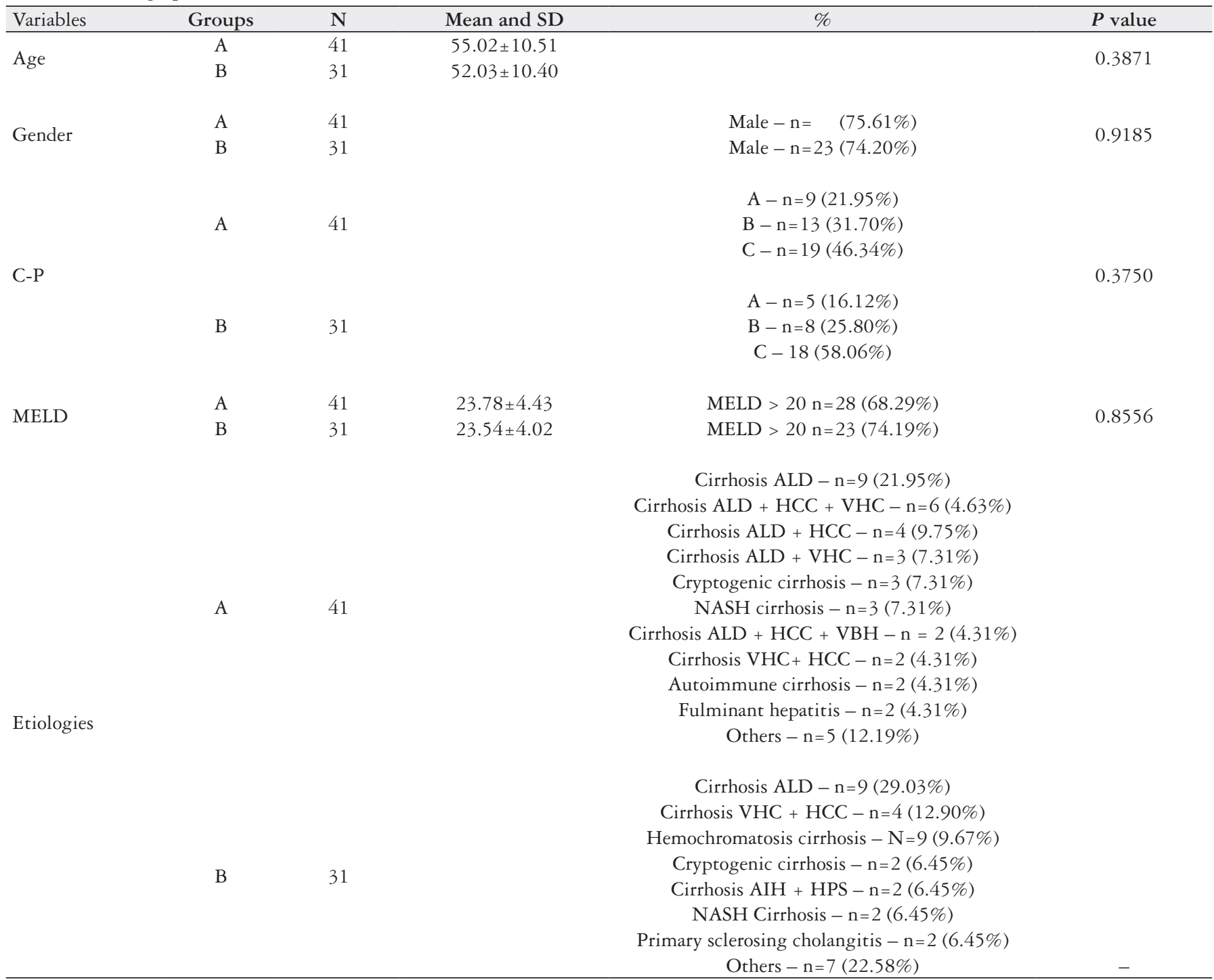

SD: standard deviation; MELD: Model for End-stage Liver Disease; ALD: alcoholic liver disease; HCC: hepatocellular carcinoma; VHC: viral hepatitis cirrhosis; VBH: virus B hepatitis; AIH autoimmune hepatitis; HPS: hepatopulmonary syndrome; C-P: Child-Pugh. 
The presence of systemic arterial hypertension was observed, on average, $9 \pm 6.98$ months after the use of immunosuppressive drugs, and the prevalence of SAH was $59.64 \%$ (41 patients). In addition, there was no statistical difference between the ages of the groups analyzed $(P=0.3871)$, as well as, there were no differences between the other clinical parameters, allowing to observe that the use of immunosuppressive drugs was the predominant factor for the development of comorbidity analysed.

The mean blood pressure measured in patients who developed SAH was systolic blood pressure of $149 \pm 10.88 \mathrm{mmHg}$ and diastolic blood pressure $92 \pm 8.82 \mathrm{mmHg}$. $63.41 \%$ (26) of the patients who developed SAH, were already diagnosed in stage I of systemic arterial hypertension, while $36.59 \%$ were diagnosed in more advanced stages, as shown in TABLE 2.

TABLE 2. Arterial pressure classification.

\begin{tabular}{lc}
\hline Classification & $\%$ \\
\hline Hypertension stage I & $63.41 \%(\mathrm{n}=26)$ \\
Hypertension stage II & $29.26 \%(\mathrm{n}=12)$ \\
Hypertension stage III & $7.31 \%(\mathrm{n}=3)$ \\
\hline
\end{tabular}

According to TABLES 3 and 4, it can be verified that there was a statistical difference between the doses of Tacrolimo prescribed when compared to the groups that developed SAH and those that did not develop SAH, as well as, we can observe the correlation between the dosage of Tacrolimo and the development of SAH.

TABLE 3. Difference between groups in relation to the type of immunosuppressive drugs used.

\begin{tabular}{lccc}
\hline Medications & Groups & Mean \pm SD dosage & $P$ value \\
\hline \multirow{2}{*}{ Tracolimo } & $\mathrm{A}-\mathrm{n}=35$ & $6.65 \pm 2.60$ & 0.0067 \\
& $\mathrm{~B}-\mathrm{n}=27$ & $4.96 \pm 2.18$ & \\
Mycophenolate & $\mathrm{A}-\mathrm{n}=35$ & $871 \pm 204$ & 0.3022 \\
& $\mathrm{~B}-\mathrm{n}=29$ & $733 \pm 289$ & \\
Cyclosporine & $\mathrm{A}-\mathrm{n}=3$ & $258 \pm 100$ & - \\
\multirow{2}{*}{ Everolimo } & $\mathrm{B}-\mathrm{n}=0$ & 0 & \\
& $\mathrm{~A}-\mathrm{n}=6$ & $2.58 \pm 1.23$ & 0.4555 \\
Azathioprine & $\mathrm{B}-\mathrm{n}=4$ & $2 \pm 0.70$ & \\
& $\mathrm{~A}-\mathrm{n}=6$ & $58.33 \pm 18.63$ & - \\
\hline
\end{tabular}

SD: standard deviation. $P<0.05=$ statistically significant difference.

TABLE 4. Correlation between immunosuppressant dosage and the presence of post-transplant hypertension.

\begin{tabular}{lccc}
\hline Medications & Groups & $\boldsymbol{P}$ value & R value \\
\hline Tacrolimo & $\mathrm{A}-\mathrm{n}=35$ & 0.0050 & 0.0067 \\
& $\mathrm{~B}-\mathrm{n}=27$ & & \\
Mycophenolate & $\mathrm{A}-\mathrm{n}=35$ & 0.2784 & 0.1322 \\
& $\mathrm{~B}-\mathrm{n}=29$ & & - \\
Cyclosporine & $\mathrm{A}-\mathrm{n}=3$ & - & \\
Everolimo & $\mathrm{B}-\mathrm{n}=0$ & & 0.2583 \\
Azathioprine & $\mathrm{A}-\mathrm{n}=6$ & 0.4711 & - \\
\hline
\end{tabular}

$P<0.05=$ statistically significant difference.
Furthermore, statistical analyses were performed regarding patients' body weight variation and presence of diabetes, as well as the evolution of creatinine in order to analyze renal injury due to hypertension, as shown in TABLE 5.

TABLE 5. Comparisons of different variables between groups.

\begin{tabular}{|c|c|c|c|}
\hline Variables & Groups & Mean and sd & $P$ value \\
\hline \multirow{2}{*}{$\begin{array}{l}\text { Body weight } \\
\text { variation }\end{array}$} & $A-n=41$ & $3.65 \pm 9.98$ & \multirow{2}{*}{0.0459} \\
\hline & $\mathrm{B}-\mathrm{n}=31$ & $-1.61 \pm 9.34$ & \\
\hline \multirow{2}{*}{ Diabetes } & $A-n=41$ & $\begin{array}{l}\text { nine pretransplant } \\
\text { patients, eight post- } \\
\text { transplant patients }\end{array}$ & \multirow[b]{2}{*}{-} \\
\hline & $B-n=31$ & $\begin{array}{l}\text { six pretransplant patients, } \\
\text { three post-transplant } \\
\text { patients }\end{array}$ & \\
\hline \multirow{2}{*}{$\begin{array}{l}\text { Creatinine - } \\
\text { month } 0\end{array}$} & $A-n=41$ & $1.36 \pm 0.9$ & \multirow{2}{*}{0.4529} \\
\hline & $B-n=31$ & $1.22 \pm 0.74$ & \\
\hline \multirow{2}{*}{$\begin{array}{l}\text { Creatinine - } \\
\text { month } 6\end{array}$} & $A-n=41$ & $1.325 \pm 0.79$ & \multirow{2}{*}{0.0061} \\
\hline & $B-n=31$ & $1.27 \pm 1.45$ & \\
\hline \multirow{2}{*}{$\begin{array}{l}\text { Creatinine - } \\
\text { month } 12\end{array}$} & $A-n=41$ & $1.26 \pm 0.55$ & \multirow{2}{*}{0.1085} \\
\hline & $B-n=31$ & $1.22 \pm 0.88$ & \\
\hline
\end{tabular}

SD: standard deviation. $P<0.05=$ statistically significant difference.

\section{DISCUSSION}

Few studies have demonstrated the time when patients were diagnosed with systemic arterial hypertension

they only show that the earlier the recognition, prevention and treatment, the better the impact on the patient's survival ${ }^{(9)}$. Thus, it was observed in this study that after $9 \pm 6.98$ months of transplantation and onset of the immunosuppressant, the patients were diagnosed and that $63.41 \%$ were in stage I of SAH; $29.26 \%$ in stage II and $7.31 \%$ in stage III.

In addition, from the data obtained, it is observed that $59.64 \%$ of patients acquired systemic arterial hypertension after liver transplantation, a value three times higher than what is expected in the general population ${ }^{(10,11)}$, but within the values found in other studies, such as Aparicio LS et al. ${ }^{(12)}$, which observed that the rates of systemic arterial hypertension after liver transplantation were $50-80 \%$.

The development of systemic arterial hypertension in the transplanted patient is associated with the use of immunosuppressive drugs, and many studies relate it to the use of cyclosporine and tacrolimus, which are calcineurin-inhibiting drugs ${ }^{(12-14)}$, since they cause endothelial dysfunction and compromises the vasodilator response, besides producing vasoconstrictor substances and activating the renin angiotensin aldosterone system. Cyclosporine is the immunosuppressive drugs which is most associated with systemic arterial hypertension ${ }^{(15,16)}$ when compared to tacrolimus. According to the article by Canzanello VJ et al. ${ }^{(17)}$, only $33 \%$ of patients who used tacrolimus developed $\mathrm{SAH}$, against those who used cyclosporine, in which $82 \%$ of patients became hypertensive. However, we observed that tacrolimus has a great correlation with systemic arterial hypertension, as $86 \%$ of transplanted patients used this drug and among them, 56\% evolved to systemic arterial hypertension. 
Although there are data that correlate mTOR (mammalian target of rapamycin inhibitors) with systemic arterial hypertension, this was not observed in our study, since the number of patients who used this drug was very small (Di Stefano C et al. ${ }^{(7)}$ ).

According to the research by Pérez MJ et al. ${ }^{\left({ }^{6}\right.}$, patients with immunosuppressive drugs use and presence of metabolic syndrome may evolve to renal failure due to reduced glomerular filtration and microalbuminuria. One of the biomarkers used for renal evaluation is the serum creatinine dosage. Therefore, this study analyzed the creatinine dosage in three moments. The first evaluation was the creatinine dosage soon after liver transplantation, in which there was no statistical difference between the groups, since both were slightly above the reference value to renal injury, which is common to occur after surgery ${ }^{(18)}$. The second evaluation occurred 6 months after the transplantation and statistical difference between the groups can be seen, inasmuch as Group A (systemic arterial hypertension group) presented higher values, when compared to Group B, this fact is in agreement with those of Pérez MJ et al. ${ }^{\left({ }^{(6)}\right.}$, which reports that the presence of metabolic syndrome due to the use of immunosuppressant increased the risk of developing renal failure. The third evaluation, in turn, showed no statistical difference between the groups, which may be associated with the onset of systemic arterial hypertension treatment and adequacy of immunosuppressive drugs levels.

Another statistical difference found between the groups was in relation to body weight variation, in which systemic arterial hypertension patients had an increase in their weight, while non-hypertensive patients had a decrease in body mass, this may be due to the fact that hypertensive patients have a higher risk for the other parameters of metabolic syndrome ${ }^{(19)}$. This higher probability of presenting the other metabolic syndrome topics can be observed in the fact that 9 hypertensive patients also had diabetes mellitus, while with the nonhypertensive patients only 3 developed diabetes mellitus.

\section{CONCLUSION}

This study shows that patients evolved to SAH on average $9 \pm 6.98$ months after using the immunosuppressant. We also found a high prevalence of systemic arterial hypertension $(59.64 \%)$ in patients post liver transplantation, who used calcineurin inhibitors, and that he use of tacrolimus has a great influence on the development of this disease, which is little evidenced in other studies.

Moreover, it has also been proved that the development of systemic arterial hypertension after transplantation indicates a greater risk for the patient to present the other parameters of metabolic syndrome as well as to evolve to kidney problems, what aggravate the morbidity and mortality of these individuals.

\section{Authors' contribution}

Lemos BO: conceptualization, data collection, formal analysis and writing of the manuscript. Silva RCMA: conceptualization, formal analysis and writing of the manuscript. Silva RF: conceptualization, supervision and writing of the manuscript.

\section{Orcid}

Bianca de Oliveira Lemos: 0000-0002-8665-734X.

Rita de Cássia Martins Alves Silva: 0000-0001-6302-0939.

Renato Ferreira da Silva: 0000-0001-9652-6426.

Lemos BO, Silva RCMA, Silva RF. Prevalência e tempo de desenvolvimento da hipertensão arterial sistêmica em pacientes após transplante de fígado. Arq Gastroenterol. 2021;58(1):77-81.

RESUMO - Contexto - O uso de imunossupressores pós-transplante de fígado (TF) está associado ao desenvolvimento de hipertensão arterial sistêmica (HAS), além de outras alterações da síndrome metabólica. Objetivo - Sendo assim, o objetivo deste estudo foi analisar a partir de quando tempo após o uso do imunossupressor o paciente evolui para HAS, assim como, identificar a sua prevalência e outros fatores que podem estar relacionados, como injuria renal. Métodos - Realizou-se um estudo retrospectivo, longitudinal, baseado em análise de 72 prontuários de pacientes, atendidos na unidade de transplante de um hospital universitário, que não apresentavam hipertensão arterial prévia, entre período de 2016 a 2019 . Resultados - Observou-se que, em média, 9 9 6,98 meses após uso do imunossupressor, os pacientes foram diagnosticados com hipertensão arterial sistêmica, sendo que a prevalência de pacientes transplantados que evoluíram para HAS, neste estudo, foi de 59,64\% (41 pacientes). Além disso, verificou-se uma correlação entre a dosagem sérica de tacrolimus e o desenvolvimento de HAS ( $P=0,0067)$, o que evidencia que o tacrolimus tem uma atuação significativa no desenvolvimento da hipertensão arterial sistêmica. Por fim, percebeu-se que o desenvolvimento de HAS pós-transplante indica um maior risco de paciente apresentar os outros parâmetros da síndrome metabólica, como também maior prejuízo na sua função renal $(P=0,0061)$. Conclusão - Este estudo mostra que os pacientes evoluíram para HAS em média 9 9 6,98 meses após o início do uso do imunossupressor. Verificou-se também alta prevalência de hipertensão arterial sistêmica $(59,64 \%)$ em pacientes pós-transplante de fígado, que usavam inibidores de calcineurina, principalmente, quando associado ao uso de tacrolimus.

DESCRITORES - Transplante de fígado. Hipertensão. Prevalência. Imunossupressores, efeitos adversos. Tacrolimo. 


\section{REFERENCES}

1. Mies S. Liver Transplantation. Rev. Assoc. Med. Bras., São Paulo, v. 44, n. 2, p. 127-134, June 1998. doi: 10.1590/s0104-42301998000200011.

2. Starzl TE, Klintmalm GBG, Porter KA, Iwatsuki S, Schroter GP. Liver transplantation with use of cyclosporin-A and prednisone. N Engl J Med. 1981;305:266-9.

3. Chagas AL, Felga GEG, Diniz MA, Silva RF, Mattos AA, Silva RCMA, et al. Hepatocellular carcinoma recurrence after liver transplantation in a Brazilian multicenter study: clinical profile and prognostic factors of survival. Eur J Gastroenterol Hepatol. 2019;31:1148-56. doi: 10.1097/MEG.0000000000001448.

4. Watt KDS, Charton MR. Metabolic syndrome and liver transplantation: A review and guide to management. J Hepatol. 2010;53:199-206. doi: 10.1016/j. jhep.2010.01.040.

5. Zheng J, Wang WL. Risk factors of metabolic syndrome after liver transplantation. Hepatobiliary Pancreat Dis Int. 2015;14:582-7. doi: 10.1016/s1499-3872(15)60037-6.

6. Pérez MJ, Grande RG, Gusmán EO, Trillo VA, López JMR. Metabolic complications in liver transplant recipients. World J Gastroenterol. 2016;22:6416-23. doi: 10.3748/wjg.v22.i28.6416.

7. Di Stefano C, Vanni E, Mirabella S, Younes R, Boano V, Mosso E. Risk factors for arterial hypertension after liver transplantation. J Am Soc Hypertens. 2018;12:220-9. doi: 10.1016/j.jash.2018.01.002.

8. Luca L, Westbrook R, Tsochatzis EA. Metabolic and cardiovascular complications in the liver transplant recipient. Ann Gastroenterol. 2015;28:183-92.

9. Watt KD, Charlton MR. Metabolic syndrome and lver transplantation: a review and guide to management, J. Hepatol. 2010;53:199-206. doi 10.1016/i. jhep. 2010.01.040

10. Passos VMA; Assis TD; Barreto SM. Arterial hypertension in Brazil: prevalence estimate from population-based studies. Epidemiol. Serv. Saúde, Brasília. 2006;15(1):35-45. doi: 10.5123/S1679-49742006000100003.
11. Lobo LAC, Canuto R, Dias da Costa JS, Pattussi MT. [Temporal trend in the prevalence of systemic arterial hypertension in Brazil]. [Article in Portuguese]. Cad. Saúde Pública. 2017;33:e00035316. doi:10.1590/0102$311 \mathrm{X} 00035316$

12. Aparicio L, Alfie J, Barochiner J, Cuffaro P, Rada M, Morales M, Galarza C, Waisman G. Hypertension: The Neglected Complication of Transplantation. ISRN Hypertension. 2013. doi: 10.5402/2013/165937.

13. Friedrich C. Luft, How calcineurin inhibitors cause hypertension, Nephrology Dialysis Transplantation. 2012;27:473-5. doi: 10.1093/ndt/gfr679

14. Textor SC, Taler SJ, Canzanello VJ, Schwartz L, Augustine JE. Posttransplantation Hypertension Related to Calcineurin Inhibitors Liver Transpl. 2000; 6:521-30.

15. Canzanello VJ, Textor SC, Taler SJ, Schwartz LL, Porayko MK, Wiesner RH, Krom RA. Late hypertension after liver transplantation: a comparison of cyclosporine and tacrolimus (FK 506). Liver Transpl. 1998;4:328-34.

16. Gojowy D, Adamczak M, Dudzicz S, Gazda M, Karkoszka H, Wiecek A. High Frequency of arterial hypertension in patients after liver transplantation. Transplant Proc. 2016;48:1721-4. doi: 10.1016/j.transproceed.2015.11.043.

17. Canzanello VJ, Schwartz L, Taler SJ, Textor SC, Wiesner RH, Porayko MK, Krom RA. Evolution of cardiovascular risk after liver transplantation: a comparison of cyclosporine A and tacrolimus (FK506). Liver Transpl Surg. 1997;3:1-9.

18. Ersoy Z, Ozdemirkan A, Zeyneloglu P, Pirat A, Torgay Adnam, Haneral M. Incidence of acute kidney injury following liver transplantation. Transplatation; 2018;102:S855. doi 10.1097/01.tp.0000543927.74859.54

19. Laish I, Braun M, Mor E, Sulkes J, Harif Y, Ben Ari Z. Metabolic syndrome in liver transplant recipients: prevalence, risk factors, and association with cardiovascular events. Liver Transpl. 2011;17:15-22. doi: 10.1002/1t.22198. 